\title{
A Case of Congenital Central Hypothyroidism Caused by a Novel Variant (GIn1255Ter) in IGSF1 Gene
}

\author{
(D) Doğa Türkkahraman1, (D) Nimet Karataş Torun², (1) Nadide Cemre Randa3 \\ 1 University of Health Sciences Turkey, Antalya Training and Research Hospital, Clinic of Pediatric Endocrinology, Antalya, Turkey \\ 2 University of Healty Sciences Turkey, Antalya Training and Research Hospital, Clinic of Pediatrics, Antalya, Turkey \\ 3University of Healty Sciences Turkey, Antalya Training and Research Hospital, Clinic of Medical Genetics, Antalya, Turkey
}

\begin{abstract}
What is already known on this topic?
Mutations in the immunoglobulin superfamily, member 1 (IGSF1) gene that mainly regulates pituitary thyrotrope function lead to X-linked hypothyroidism characterized by congenital hypothyroidism of central origin and testicular enlargement. The clinical features associated with IGSF1 mutations are variable, but prolactin and/or growth hormone deficiency, and discordance between timing of testicular growth and rise of serum testosterone levels could be seen.
\end{abstract}

\section{What this study adds?}

Genetic analysis revealed a novel c.3763C > T variant in the IGSF1 gene. To our knowledge, this is the first reported case of IGSF1 deficiency from Turkey. Additionally, as in our case, early testicular enlargement but delayed testosterone rise should be evaluated in all boys with central hypothyroidism, as macro-orchidism is usually seen in adulthood.

\begin{abstract}
Loss-of-function mutations in the immunoglobulin superfamily, member 1 (IGSF1) gene cause X-linked central hypothyroidism, and therefore its mutation affects mainly males. Central hypothyroidism in males is the hallmark of the disorder, however some patients additionally present with hypoprolactinemia, transient and partial growth hormone deficiency, early/normal timing of testicular enlargement but delayed testosterone rise in puberty, and adult macro-orchidism. Here, we report a boy with congenital central hypothyroidism caused by a novel variant in the IGSF1 gene. In our patient, early testicular enlargement but delayed testosterone rise with central hypothyroidism and hypoprolactinemia were the most important clues for diagnosis. In genetic analysis, we identified a novel, hemizygous nonsense c.3763 C > T (G1n1255Ter) variant in IGSF1 gene. To our knowledge, this is the first reported case of IGSF1 deficiency from Turkey. Keywords: Central hypothyroidism, hypoprolactinemia, IGSF1
\end{abstract}

\section{Introduction}

Congenital central hypothyroidism $(\mathrm{CCH})$ is a rare disease characterized by impaired thyrotropin secretion with a normal thyroid gland. The pathogenic mechanism of $\mathrm{CCH}$ is heterogeneous and dysfunction of thyrotroph-specific genes such as the thyroid-stimulating hormone $\beta$-subunit and thyrotrophin releasing hormone (TRH) receptor (TRHR) can result in isolated central hypothyroidism $(1,2)$. Many $\mathrm{CCH}$ patients, however, have additional pituitary hormone deficiencies (3). Some patients with combined pituitary hormone deficiencies were reported to carry mutations in transcription factors genes involved in pituitary development, including POU1F, PROP1, HESX1, and LHX3 (4). Recently, loss-of-function mutations in the immunoglobulin
Address for Correspondence: Doğa Türkkahraman MD, University of Health Sciences Turkey, Antalya Training and Research Hospital, Clinic of Pediatric Endocrinology, Antalya, Turkey

Phone: +90 5052501396 E-mail: drdoga@hotmail.com ORCID: orcid.org/0000-0002-7472-5712
Conflict of interest: None declared Received: 02.07.2020 Accepted: 04.08.2020 
superfamily, member 1 (IGSF1) gene have been described as an X-linked cause of $\mathrm{CCH}$ with an estimated prevalence of $1 / 100,000(5,6)$. Central hypothyroidism in males is the hallmark of the disorder. However, some patients additionally present with hypoprolactinemia, transient and partial growth hormone deficiency (GHD), early/normal timing of testicular enlargement but delayed testosterone rise in puberty resulting in delayed adolescent growth spurt, and adult macro-orchidism (7). The IGSF1 gene resides on the X-chromosome (Xq 26.2) and therefore its mutation affects mainly males, although some female heterozygous carriers may present with central hypothyroidism (7). IGSF1 encodes a plasma membrane immunoglobulin superfamily glycoprotein (8). After proteolytic cleavage, the C-terminal portion traffics to the plasma membrane where it is expressed as a large extracellular domain, suggesting a possible function in cell-cell adhesion or signaling (9). IGSF1 is mainly expressed in Rathke's pouch, adult pituitary gland, and the hypothalamus $(5,10)$.

Here we report a boy with $\mathrm{CCH}$ caused by a novel variant in the IGSF1 gene. In our patient, early testicular enlargement but delayed testosterone rise with central hypothyroidism and hypoprolactinemia were the most important clues for the diagnosis. Additionally, to our knowledge, this is the first reported case of IGSF1 deficiency from Turkey.

\section{Case Report}

A 10.1 year-old boy was referred to our pediatric endocrinology out-patient clinic for hypothyroidism. He has been followed up in another hospital due to congenital hypothyroidism, and using levothyroxine $(1.7 \mathrm{mcg} / \mathrm{kgper}$ day). His medical history revealed that he was born at term with $3240 \mathrm{~g}$ weight without perinatal hypoxia. His mentalmotor development was normal. He had used short-term growth hormone therapy two years earlier. His parents were not consanguineous, and had no history of hypothyroidism.

In physical examination, height was $135 \mathrm{~cm}$ [-0.55 standard deviation score (SDS)] and weight was $37 \mathrm{~kg}(+0.62$ SDS). Thyroid gland was not palpable, bilateral testicular volumes were $6 \mathrm{~mL}$, and penis stretched length was $4 \mathrm{~cm}$ without pubarche. Target height was $170 \mathrm{~cm}$ (-0.92 SDS). Laboratory findings were as follows; fT4: $0.59 \mathrm{ng} / \mathrm{dL}(0.61$ 1.68); ree triiodothyronine (fT3): $3.46 \mathrm{ng} / \mathrm{dL}$ (2.9-6.1); thyroid stimulating hormone (TSH): $0.02 \mathrm{uIU} / \mathrm{mL}$ (0.37-5.1); thyroglobulin: $10.7 \mu \mathrm{g} / \mathrm{L}(3.5-41)$; prolactin $0.76 \mu \mathrm{g} / \mathrm{L}$ (2.6413.13); and thyroid auto-antibodies were negative. Thyroid ultrasonography revealed a hypoplastic thyroid gland with a total volume of $0.9 \mathrm{~mL}$. Levothyroxine dosage was increased until euthyroidism was achieved. Bone age was nine years. There was a $38 \mathrm{~mm}$ arachnoid cyst in the right temporal pole on brain magnetic resonance imaging, and pituitary gland was normal in structure. Growth hormone deficiency was excluded on follow-ups. His growth rate and insulin-like growth factor-1 (IGF-1) level (120.3 $\mu \mathrm{g} / \mathrm{L})$ were normal for his age. Total testosterone was low (0.01 $\mu \mathrm{g} / \mathrm{L}$ ), and other laboratory tests (morning basal values) were as follows; luteinizing hormone (LH): $0.01 \mathrm{U} / \mathrm{L}$; folliclestimulating hormone (FSH): $0.65 \mathrm{U} / \mathrm{L}$; adrenocorticotropic hormone (ACTH): $8.9 \mathrm{ng} / \mathrm{L}(4.7-48.8)$; and cortisol: $7 \mu \mathrm{g} / \mathrm{dL}$ (6.7-22.6). Low dose ACTH stimulation test was performed, and peak cortisol level was found to be normal $(22.1 \mu \mathrm{g} / \mathrm{dL})$. Additionally, on TRH stimulation test, peak TSH response was very low $(0.01 \mathrm{uIU} / \mathrm{mL})$ confirming the pituitary central hypothyroidism. Laboratory findings of the mother were normal: free thyroxine (fT4): $1.1 \mathrm{ng} / \mathrm{dL} ; \mathrm{fT} 3: 4.2 \mathrm{ng} / \mathrm{dL}$; TSH: $3.3 \mathrm{uIU} / \mathrm{mL}$; and prolactin $16 \mu \mathrm{g} / \mathrm{L}$. fT4, TSH and prolactin levels of the father and the two other siblings (one sister and one brother) were also normal.

At the age of 11.9 years, his bilateral testicular volumes were 6-8 mL without pubarche. Laboratory tests were as follows: total testosterone: $0.07 \mathrm{ng} / \mathrm{mL}$ (0.21-0.82); LH: $0.13 \mathrm{U} / \mathrm{L}$; FSH: $1.85 \mathrm{U} / \mathrm{L}$; dehydroepiandrosterone sulfate (DHEAS): $48 \mu \mathrm{g} / \mathrm{dL}$ (20-550); androstenedione: $0.3 \mathrm{ng} / \mathrm{mL}$ (0.3-0.6); 11 -deoxycortisol $0.41 \mathrm{ng} / \mathrm{mL}(0.2-1.5) ; 17-O H$ progesterone: $1.5 \mathrm{ng} / \mathrm{mL}$ (0.5-1.5); and anti-Mullerian hormone: 24.2 $\mathrm{ng} / \mathrm{mL}$ (28.4-113.8). As a result, IGSF1 gene mutation was considered in the patient because of central hypothyroidism, hypoprolactinemia, and low testosterone level incompatible with testicular volume.

After written informed consent was provided from the parents, genetic analysis with next gene sequencing (Illumina, NovaSeq, 6000, San Diego, California, United States) was performed. A novel hemizygous nonsense c.3763C > T (G1n1255Ter) variant in the IGSF1 gene was identified (Figure 1). We considered this variant as pathogenic by using American College of Medical Genetics (ACMG) criteria (11). According to the ACMG criteria IGSF C.3763C > T variant met the criteria for PVS1, PM2 and PP4. The explanations of these criteria are as follows; its nonsense nature and loss of function is a known mechanism for central hypothyroidism (PVS1), absence in population databases (PM2), and compatible clinical findings with IGSF1 gene mutations (PP4). Sanger sequencing was performed in the patient's mother, and she was found as an obligate carrier (Figure 2). Unfortunately, other relatives of the mother did not consent for genetic analysis. 


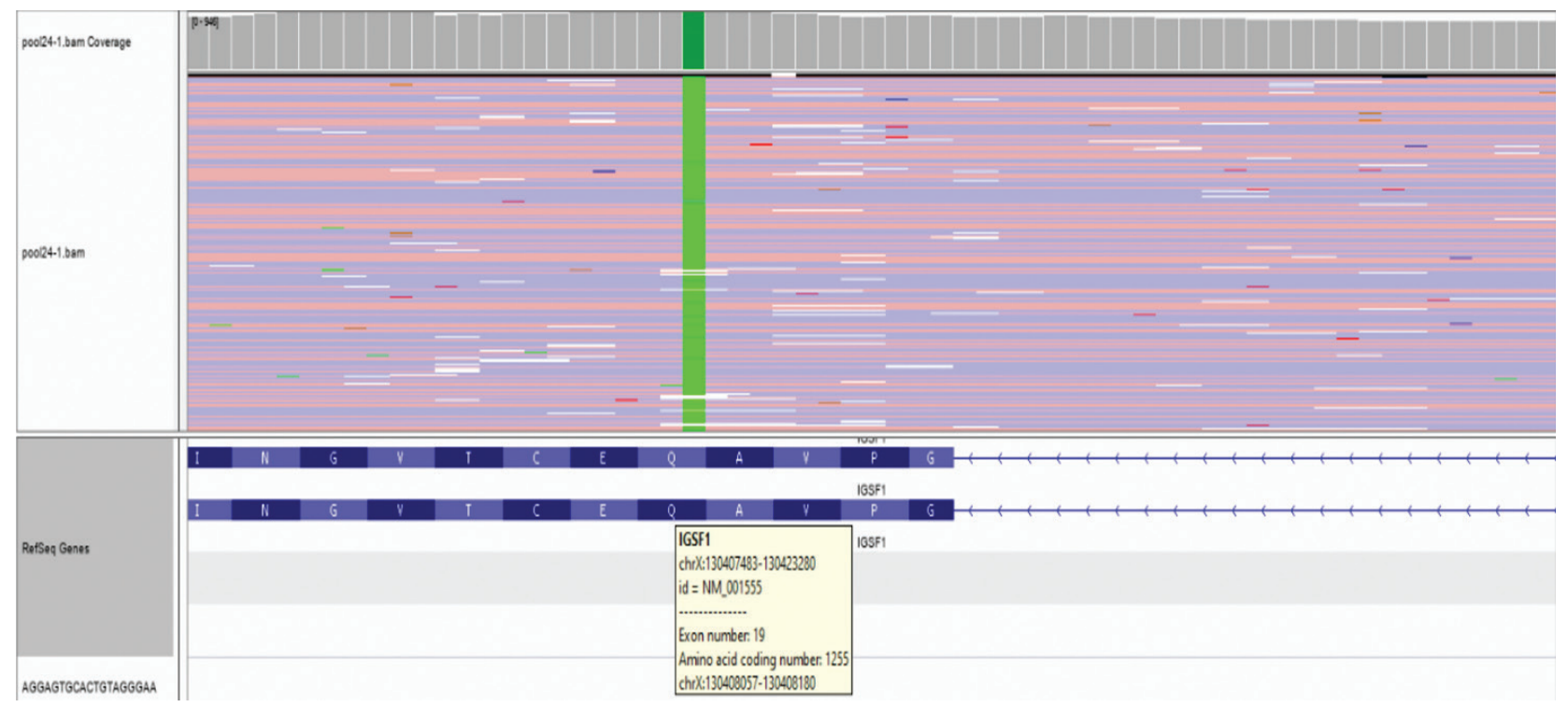

Figure 1. Next gene sequencing image of the novel hemizygous c.3763C > T change in IGSF1 gene of the patient

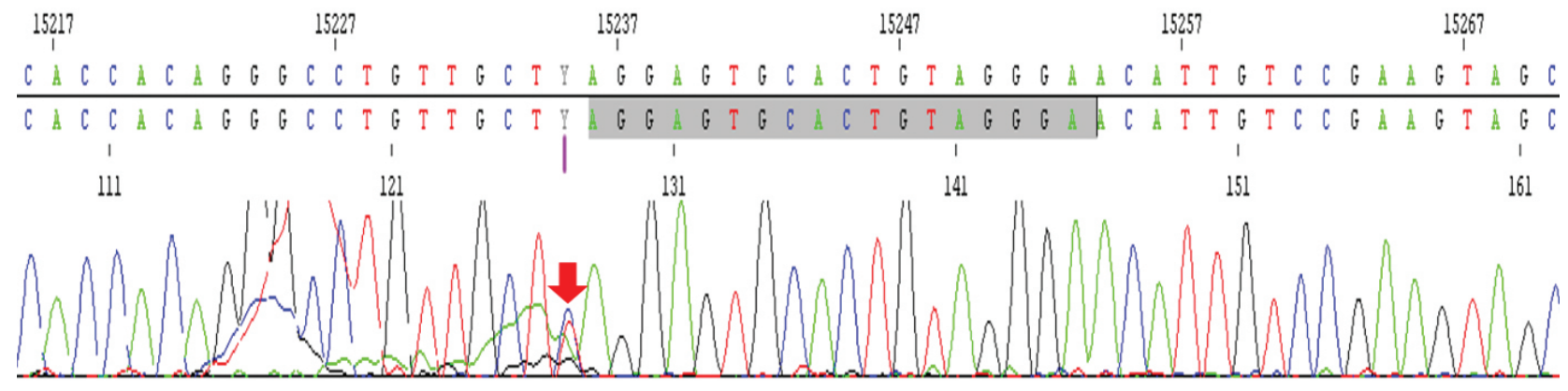

Figure 2. Sanger sequencing image of heterozygous C.3763C > T change in IGSF1 gene of the patient's mother

\section{Discussion}

The IGSF1 protein contains 12 immunoglobulin-like domains in two clusters, which are separated by a linker segment and followed by a transmembrane and a cytoplasmic region (12). Lack of IGSF1 protein impairs glycosylation and trafficking of the protein to the cell surface. Therefore, mutations in IGSF1 gene that mainly regulates pituitary thyrotrope function lead to X-linked hypothyroidism characterized by congenital hypothyroidism of pituitary origin. The clinical features associated with IGSF1 mutations are variable, but prolactin and/or growth hormone deficiency, discordance between timing of testicular growth and rise of serum testosterone levels, and abnormal weight gain may be seen (5). In a recent study, pituitary central hypothyroidism was found as the cardinal finding of the disease (100\% in the cases), however only $62 \%$ had prolactin deficiency, and the remaining patients had normal prolactin secretion. Interestingly, prolactin deficiency was not consistent in patients from the same family who carry the same mutations. The reason for this variability is unknown but might be caused by interplay of several gene polymorphisms (13). In the same study, the rate of transient GH deficiency was $11 \%$. Surprisingly, all children with GH deficiency had normal IGF-1 levels, whereas adults had higher than normal IGF-1 levels. Many of the children with GH deficiency were retested in adulthood and found to have normal results on GH stimulation tests. Additionally, delayed pubertal testosterone rise, and early/ normal timing of testicular growth was found in $75 \%$ of the patients in this cohort. In our case, pubertal testicular volume without pubarche and with low testosterone level prompted us to consider IGSF1 deficiency.

Another important issue in these patients is adrenal function. Hypocortisolism was diagnosed in $21 \%$ of newborns. However, this proved to be transient within a few years in all cases (13). The late adrenarche in patients with prolactin deficiency is another clue for adrenal dysfunction. 
However, this is considered to occur as a result of prolactin deficiency. Prolactin receptors are highly expressed in the adrenal gland and are stimulated by ACTH to increase adrenal androgen secretion (14). Furthermore, DHEAS levels are usually found elevated in hyperprolactinemia, and lowering of prolactin concentration decreases DHEAS level. In our case, the patient has delayed pubarche with low DHEAS and androstenedione levels for his age without adrenal insufficiency.

A small proportion of heterozygous females may also show central hypothyroidism, prolactin deficiency and delayed menarche. Heterozygous females carrying IGSF1 mutations generally exhibit fT4 levels in the lower tertile of the normal range with nearly $20 \%$ fulfilling the criteria for central hypothyroidism. Up to $20 \%$ of the cases demonstrate hypoprolactinemia, and to date four females have been reported to have surgery for benign ovarian cysts (13). In our case, the mother was an obligate carrier, and had neither hypothyroidism nor hypoprolactinemia.

\section{Conclusion}

In conclusion, in the present case, genetic analysis revealed a novel c.3763C $>\mathrm{T}$ variant in the IGSF1 gene. To our knowledge, this is the first reported case of IGSF1 deficiency from Turkey. Early testicular enlargement but delayed testosterone rise with central hypothyroidism and hypoprolactinemia were the most important clues for the diagnosis. Importantly, as in our case, early testicular enlargement but delayed testosterone rise should be evaluated in all boys with central hypothyroidism, as macro-orchidism is only usually seen late in adulthood. Additionally, although the current clinical findings of the patient are sufficient for the diagnosis and treatment of central hypothyroidism, genetic diagnosis played a key role in management and follow-up of the patient.

\section{Ethics}

Informed Consent: Written informed consent was provided from the parents.

Peer-review: Internally peer-reviewed.

\section{Authorship Contributions}

Concept: Doğa Türkkahraman, Design: Doğa Türkkahraman, Data Collection or Processing: Doğa Türkkahraman, Nadide Cemre Randa, Analysis or Interpretation: Doğa Türkkahraman, Nadide Cemre Randa, Literature Search: Doğa Türkkahraman, Nimet Karataş Torun, Writing: Doğa
Türkkahraman, Nimet Karataş Torun, Nadide Cemre Randa.

Financial Disclosure: The authors declared that this study received no financial support.

\section{References}

1. Matsubara K. A single base substitution in the CAGYC region of the $\beta$-subunit. EMBO J 1989;8:2291-2296.

2. Collu R, Tang J, Castagné J, Lagacé G, Masson N, Huot C, Deal C, Delvin E, Faccenda E, Eidne KA, Van Vliet G. A novel mechanism for isolated central hypothyroidism: Inactivating mutations in the thyrotropin-releasing hormone receptor gene. J Clin Endocrinol Metab 1997;82:1561-1565.

3. Van Tijn D, De Vijlder JJM, Verbeeten B, Verkerk PH, Vulsma T. Neonatal detection of congenital hypothyroidism of central origin. J Clin Endocrinol Metab 2005;90:3350-3359. Epub 2005 Mar 22

4. Miyai K. Congenital thyrotropin deficiency. Endocr J 2007;54:191-203. Epub 2007 Feb 8

5. Sun Y, Bak B, Schoenmakers N, van Trotsenburg AS, Oostdijk W, Voshol P, Cambridge E, White JK, le Tissier P, Gharavy SN, MartinezBarbera JP, Stokvis-Brantsma WH, Vulsma T, Kempers MJ, Persani L, Campi I, Bonomi M, Beck-Peccoz P, Zhu H, Davis TM, Hokken-Koelega AC, Del Blanco DG, Rangasami JJ, Ruivenkamp CA, Laros JF, Kriek M, Kant SG, Bosch CA, Biermasz NR, Appelman-Dijkstra NM, Corssmit EP, Hovens GC, Pereira AM, den Dunnen JT, Wade MG, Breuning MH, Hennekam RC, Chatterjee K, Dattani MT, Wit JM, Bernard DJ. Loss-offunction mutations in IGSF1 cause an X-linked syndrome of central hypothyroidism and testicular enlargement. Nat Genet 2012;44:13751381. Epub 2012 Nov 11

6. Joustra SD, van Trotsenburg AS, Sun Y, Losekoot M, Bernard DJ, Biermasz NR, Oostdijk W, Wit JM. IGSF1 deficiency syndrome: a newly uncovered endocrinopathy. Rare Dis 2013;1:e24883.

7. Joustra SD, Schoenmakers N, Persani L, Campi I, Bonomi M, Radetti G, Beck-Peccoz P, Zhu H, Davis TM, Sun Y, Corssmit EP, AppelmanDijkstra NM, Heinen CA, Pereira AM, Varewijck AJ, Janssen JA, Endert E, Hennekam RC, Lombardi MP, Mannens MM, Bak B, Bernard DJ, Breuning $\mathrm{MH}$, Chatterjee $\mathrm{K}$, Dattani MT, Oostdijk W, Biermasz NR, Wit JM, van Trotsenburg AS. The IGSF1 deficiency syndrome: characteristics of male and female patients. J Clin Endocrinol Metab 2013;98:4942-4952. Epub 2013 Oct 9

8. Mazzarella R, Pengue G, Jones J, Jones C, Schlessinger D. Cloning and expression of an immunoglobulin superfamily gene (IGSF1) in Xq25. Genomics 1998;48:157-162.

9. Robakis T, Bak B, Lin S, Bernard DJ, Scheiffele P. An internal signal sequence directs intramembrane proteolysis of a cellular immunoglobulin domain protein. J Biol Chem 2008;283:36369-36376. Epub 2008 Nov 3

10. Joustra SD, Meijer OC, Heinen CA, Mol IM, Laghmani el H, Sengers RM, Carreno G, van Trotsenburg AS, Biermasz NR, Bernard DJ, Wit JM, Oostdijk W, van Pelt AM, Hamer G, Wagenaar GT. Spatial and temporal expression of immunoglobulin superfamily member 1 (IGSF1) in the rat. J Endocrinol 2015; 226:181-191. Epub 2015 Jul 10

11. Richards S, Aziz N, Bale S, Bick D, Das S, Gastier-Foster J, Grody WW, Hegde M, Lyon E, Spector E, Voelkerding K, Rehm HL; ACMG Laboratory Quality Assurance Committee. Standards and guidelines for the interpretation of sequence variants: a joint consensus recommendation of the American College of Medical Genetics and 
Genomics and the Association for Molecular Pathology. Genet Med 2015;17:405-424

12. Frattini A, Faranda S, Redolfi E, Allavena P, Vezzoni P. Identification and genomic organization of a gene coding for a new member of the cell adhesion molecule family mapping to Xq25. Gene 1998;214:1-6.

13. Joustra SD, Heinen CA, Schoenmakers N, Bonomi M, Ballieux BE, Turgeon MO, Bernard DJ, Fliers E, van Trotsenburg AS, Losekoot M,
Persani L, Wit JM, Biermasz NR, Pereira AM, Oostdijk W; IGSF1 Clinical Care Group. IGSF1 deficiency: lessons from an extensive case series and recommendations for clinical Management. J Clin Endocrinol Metab 2016;101:1627-1636. Epub 2016 Feb 3

14. Bole-Feysot C, Goffin V, Edery M, Binart N, Kelly PA. Prolactin (PRL) and its receptor: actions, signal transduction pathways and phenotypes observed in PRL receptor knockout mice. Endocr Rev 1998;19:225268. 